\title{
Types of Weed and Their Potentials as the Host Plant of Parasitic Nematodes in Arabica and Robusta Coffee Plant in Kalibendo Banyuwangi
}

\author{
Tommy Murdiono, Iis Nur Asyiah, Pujiastuti \\ Department of MIPA Education, Faculty of Teacher Training and Education, Jember University \\ Jalan. Kalimantan 37, Jember 68121 \\ e-mail: murdiono.tommy12@gmail.com
}

\begin{abstract}
This study aimed to determine the type of weed and its potential as parasite nematode host plants in arabica and robusta plantations. This study included a qualitative exploratory research where weed sampling was carried out by roaming in the area of Arabica and Robusta coffee plantations. Various types of weeds were taken, identified, and then extracted its root to find out the existence of nematodes. The result showed that there were 8 species of weeds where nematodes can be found in their roots. Those weeds were Tuton (Paspalum mandiocanum), Oxtail (Heliotropium indicum), Paku (Davallia denticulata), Pendul (Kyllinga brevifolia). Sintrong (Crassocephalum crepidioides), Bandotan (Ageratum conyzoides), Oplismenus hirtellus, Princess shame (Mimosa invisa). The result of nematodes identification revealed that it was Pratilenchus coffeae, a common parasitic nematode that attacks coffee.
\end{abstract}

Keywords: weed type, alternative weed nematode host, coffee.

\section{INTRODUCTION}

Parasitic nematodes are one of the plant disturbing organisms (PDO) that attack various types of cultivated plants. In Indonesia, 26 species of parasitic nematodes have been identified that attack food crops, (Mustika, 2005).

According to Tjokrowardojo and Djauhariya (2013), weed is a problem for coffee plants. In addition to weeds that interfere with coffee plants, there are also disturbing organisms, namely pests and diseases among other nematodes. One of them is Pratilenchus coffeae and Radopholus nematodes which attack the roots of arabica and robusta coffee plants. Because in the same environment, weeds can potentially become secondary hosts for nematodes.

In general, nematode attacks cause damage to the roots, because nematodes suck the root cells, so the tissue vessels are disrupted, resulting in water and nutrient translocation being hampered (Evans, 1982cds; Melakeberhan et al., 1987), so that plant growth is inhibited, the color of the leaves turns yellow like symptoms of nutrient deficiency, and easily withers. Because growth is hampered, crop productivity decreases.

Nematodes are generally polyphagous since they attack more than one type of plant. In addition to cultivated plants, nematodes also have a tendency to make weeds into their host plants. Weeds are plants that grow in areas of cultivated cropland and adversely affect human needs. Weeds can harm cultivation plants, reduce the quality and quantity of results, being host to pests and diseases and disturbing scenery. (Perkasa, 2011).

The existence of alternative hosts that can stimulate the problem of nematodes, namely $P$. coffeae and Radopholus nematodes. In addition, weeds are also an alternative host of nematodes, so the presence of weeds can stimulate nematode problems in coffee plants (Swibawa, 2009). Coffee is a plant that grows well in tropical regions. Indonesia, which is one of the countries with a tropical climate, is suitable as a good growing place for coffee. Demand for Indonesian coffee continues to increase over time (Ditjenbun, 2015).

\section{RESEARCH METHODS}

This research is included in the type of 
qualitative research. Weed sampling by exploration in the plantation area, identification of weeds, extracts of weed roots, are done to find out the types of weeds that are alternative nematode hosts.

The study was conducted from December $20^{\text {th }}, 2017$ to March $20^{\text {th }}, 2018$ in Kalibendo, Banyuwangi, extraction at the Laboratory of the Faculty of Agriculture, University of Jember, and observing nematodes in the Laboratory of the Faculty of Dentistry, University of Jember.

\section{RESULTS}

Results of Measurement of Environmental Factors. The results of measurements of environmental factors include air temperature, air humidity, soil $\mathrm{pH}$, and height of the location. The used environmental measuring instruments are Thermo hygrometer (temperature and humidity), Soiltester ( $\mathrm{pH}$ and soil moisture), Altimeter (altitude). Listed in the table below.

Table 1. Measurement of Abiotic Factors, namely temperature, humidity, soil $\mathrm{pH}$ in the area of Robusta:

\begin{tabular}{|c|c|c|c|}
\hline \multicolumn{4}{|c|}{ Robusta } \\
\hline $\begin{array}{c}\text { Factors } \\
\text { Afternoon }\end{array}$ & morning & day & Afternoon \\
\hline Air humidity & $63 \%$ & $59 \%$ & $56 \%$ \\
\hline $\begin{array}{c}\text { Air } \\
\text { temperature }\end{array}$ & $30^{\circ} \mathrm{C}$ & $31^{\circ} \mathrm{C}$ & $28^{\circ} \mathrm{C}$ \\
\hline soil pH & 6,8 & 6,9 & 6,9 \\
\hline Soil moisture & $1,8 \%$ & $1,8 \%$ & $1,8 \%$ \\
\hline Altitude & $\begin{array}{c}558 \\
\text { masl }\end{array}$ & $\begin{array}{c}558 \\
\text { masl }\end{array}$ & $\begin{array}{c}558 \\
\text { masl }\end{array}$ \\
\hline
\end{tabular}

Found weeds and the number of nematodes found at the root of the weed are: Harendong (Clidemia hirta), Tuton (Paspalum mandiocanum) 13 nematodes were found, Mouse Tail (Heliotropium indicum) 20 nematodes were found, Paku (Davallia denticulata) 6 nematodes were found, Pegagan (Centella asiatica) Thlaspi arvense Buttoned grass (Borreria laevis) Axonopus compresus. Pendul (Kyllinga brevifolia) 10 nematodes were found. Sintrong (Crassocephalum crepidioides) 13 nematodes were found Bandotan nematodes (Ageratum conyzoides) 10 nematodes were found. Taro (Colocasia esculenta). Princess embarrassed (Mimosa invisa) 13 nematodes were found. Oxalis barrelieri. Mikania micrantha, Erigeron sumatrensis. Diodia sarmentosa. Oplismenus hirtellus 16 nematodes were found. Phyllanthus debilis

Table 2. Measurement of abiotic factors, namely temperature, humidity, soil $\mathrm{pH}$ in Arabica:

\begin{tabular}{|c|c|c|c|}
\hline \multicolumn{4}{|c|}{ Arabica } \\
\hline $\begin{array}{c}\text { Factors } \\
\text { Afternoon }\end{array}$ & morning & day & Afternoon \\
\hline Air humidity & $69 \%$ & $65 \%$ & $67 \%$ \\
\hline $\begin{array}{c}\text { Air } \\
\text { temperature }\end{array}$ & $28^{\circ} \mathrm{C}$ & $31^{\circ} \mathrm{C}$ & $29^{\circ} \mathrm{C}$ \\
\hline soil pH & 7,0 & 7,0 & 6,9 \\
\hline Soil moisture & $2 \%$ & $1,9 \%$ & $1,9 \%$ \\
\hline Altitude & $\begin{array}{c}755 \\
\text { masl }\end{array}$ & $\begin{array}{c}755 \\
\text { masl }\end{array}$ & $\begin{array}{c}755 \\
\text { masl }\end{array}$ \\
\hline
\end{tabular}

After the identification on in Arabica area has been done, types of the weed and the number of nematodes which are found in the weed roots are Harendong (Clidemia hirta), Tuton (Paspalum mandiocanum) 30 nematodes were found. Oxtail Rat (Heliotropium indicum) 36 nematodes were found. Paku (Davallia denticulata) 23 nematodes were found. Gotu kola (Centella asiatica). Thlaspi arvense. Buttoned grass (Borreria laevis). Axonopus compresus. Pendul (Kyllinga brevifolia) 13 nematodes were found. Sintrong (Crassocephalum crepidioides) 46 nematodes were found Bandotan (Ageratum conyzoides) 20 nematodes were found. Oxalis barrelieri. Sembung rambat (Mikania micrantha). Erigeron sumatrensis. Diodia sarmentosa. Oplismenus hirtellus 23 nematodes were found. Phyllanthus debilis.

\section{DISCUSSION}

This research aims to identify and inventory weeds found in Arabica and Robusta coffee plantation to find out the weeds that potentially can be the alternative host of parasitic nematode.

\section{Weed identification and inventory at Arabica and Robusta plantations.}

Types of Weed and Their Potential as The Host Plant of Parasitic Nematodes in Arabica and Robusta Coffee Plantation Kalibendo,

Bioedukasi Vol. XVI. No. 2 Oktober 2018 
Banyuwangi has been done. Identification was carried out on samples of various types of weed plants found in Arabica and Robusta plantations. The number of species found in the Arabica area is 17 types of weeds and Robusta 19 types of weeds. There are 19 types of weeds that have been successfully identified based on the WEEDS OF RICE IN INDONESIA book, Weed Control Books, ITIS and Plantamor. Identification of nematodes is based on the Nematode Control book.

The results showed that in the Arabica and Robusta coffee plantation in Kalibendo, Banyuwangi, there are 19 species of weed species. Weed species correspond to, Harendong (Clidemia hirta), Tuton (Paspalum mandiocanum), Oxtail (Heliotropium indicum), Paku (Davallia denticulata), Pegagan (Centella asiatica), Thlaspi arvense, Purple Buttoned Grass (Borreria laevis), Axonopus compresus, Pendul (Kyllinga brevifolia), Sintrong (Crassocephalum crepidioides), Bandotan (Ageratum conyzoides), Taro-taro (Colocasia esculenta), Putri malu (Mimosa invisa), Oxalis barrelieri, Sembung rambat (Mikania micrantha), Erigeron sumatrensis, Diodia sarmentosa, Oplismenus hirtellus, Phyllanthus debilis. Weed growth is influenced by supporting environmental factors in the two different locations. The other environmental factors in Arabica in the morning are: Humidity $69 \%$, air temperature $28 \mathrm{oC}$, soil temperature $23 \mathrm{oC}$, soil $\mathrm{pH}$ 7.0, height $750 \mathrm{~m}$ above sea level, in the Robusta area in the morning, namely: 63\% humidity, air temperature $300 \mathrm{C}$, soil temperature $23 \mathrm{oC}$, soil $\mathrm{pH} 6.8$, height 553 meters above sea level.

The sample results obtained from 2 sampling areas, which are generally spread around Arabica and Robusta coffee plants. From the samples obtained not all types of weeds become the alternative host of parasitic nematodes. After verification or extraction at the weed roots, it is known that 8 of the 19 types of weeds became an alternative host of parasitic nematodes, namely: Paspalum mandiocanum, Rat tail (Heliotropium indicum), Paku (Davallia denticulata), Pendul (Kyllinga brevifolia). Sintrong (Crassocephalum crepidioides), Bandotan (Ageratum conyzoides), Oplismenus hirtellus,
Princess shame (Mimosa invisa). This is supported by the opinion of Leo E. Bendixen, 1988. Weeds that host Pratylenchus nematodes include: Digitaria sanguinalis, or type of convoluted grass, Echinochloa, Ageratum conyzoides. This statement is also strengthened by Weed Teknologi, 2010. That weeds that have the potential to become nematode houses include Ageratum conyzoides, Echinochloa, Mikania micrantha.

Weed found the highest number of nematodes in these two areas is sintrong (Crassocephalum crepidioides) which is 46 and the Rat Tail (Heliotropium indicum) which is 36 in the Arabica coffee area. Of all types of weeds, it is known that nematodes are most commonly found in Arabica coffee area, due to the different levels of humidity, temperature, air temperature, and the altitude in the Robusta area. This also affects the number of nematodes existing in the coffee area. From the identification of weeds, there are no special characteristics or symptoms seen in weeds that are host to nematodes. Weeds are seen to grow normally, look fresh, not wilted and the leaves are still intact. None of them fall or fall out, as in the case where cultivated plants attacked by nematodes.

\section{Types of parasitic nematodes found in weeds in the area of Arabica and Robusta coffee.}

Based on the identification of nematodes found is Pratylenchus coffeae, long worm-like bodies with very slow motion, stylet-equipped, stylet not too long and rather fat, clear knob basal, this is also in accordance with Castilo and Volvas, 2007. Nematodes Pratylenchus coffeae. The characteristics of having a stylet are clear, the shape of the stylet is not too long and rather fat with a clear basal knob, used to suck nutrients or liquid plant cells for life's needs. Pratylenchus coffeae stylet size is 2.4 $\mu \mathrm{m}$. Nematodes found in weeds, Pratyleenchus coffeae, are the same as nematodes that attack coffee cultivation plants, namely Pratylenchus coffea which attacks coffee plants.

Through the discovery of the weeds that become host then it is clear that the nematode will continue to develop and reproduce and look for other alternative hosts. Based on the data above, it is known that 6 weed family types are alternative hosts of parasitic

Bioedukasi Vol. XVI. No. 2 Oktober 2018 
nematodes namely: Poaceae, Heliotropiaceae, Davalliaceae, Cyperaceae, Asteraceae, and Fabaceae. From the data in accordance with the statement. Weeds are considered to host Pratylenchus and reproduce, namely the Asteraceae, Poaceae and Cyperaceae families. This is also supported by Weed Technology, 2010. Weed of the families of Asteraceae, Poaceae, Fabaceae, and Cyperaceae. It is known to be a potential host for nematodes.

Based on the six types of weed families that are verified as an alternative to the nematode host, this is in accordance with the opinion of Anwar and Mc Kenry, 2002. Monocot weeds are more potential to host nematodes compared to the dicotyl because they have fibrous roots and their size is relatively small so that the nematode larvae more easily penetrate and reproduce in the roots of monocot weeds. Nematodes penetrate and reproduce more easily in weeds with softtextured monocot roots than hard-textured roots. Mature nematodes will come out of the host and attack the main plants for life. Nematodes attack dicotyl weeds plants not as temporary breeding sites. In dicotyledonous plants, there are certain nutrients that trigger the nematodes to come.

\section{CONCLUSION}

It is known that arabica and robusta plantations have found 19 types of weeds, namely: Harendong (Clidemia hirta), Tuton (Paspalum mandiocanum), Oxtail (Heliotropium indicum), Paku (Davallia denticulata), Pegagan (Centella asiatica), Thlaspi arvense, Buttoned grass (Borreria laevis), Axonopus compresus, Pendul (Kyllinga brevifolia), Sintrong (Crassocephalum crepidioides), Bandotan (Ageratum conyzoides), Taro (Colocasia esculenta), Princess embarrassment (Mimosa invisa), Oxalis barrelieri, Sembung rambat (Mikania micrantha), Erigeron sumatrensis, Diodia sarmentosa, Oplismenus hirtellus, Phyllanthus debilis. After weed identification and inventorization, it was found that 8 of the

Swibawa, IG 2009. Nematode diversity after conversion of forests into coffee plantations. Dissertation of the S-3 Program of the Faculty of Agriculture Universitas
19 types of weeds became an alternative host of parasitic nematodes, namely: Tuton (Paspalum mandiocanum), Mouse Tail (Heliotropium indicum), Paku (Davallia denticulata), Pendul (Kyllinga brevifolia). Sintrong (Crassocephalum crepidioides), Bandotan (Ageratum conyzoides), Oplismenus hirtellus, Princess shame (Mimosa invisa).

\section{REFERENCES}

Anwar, SA and MV McKenry. 2002. Developmental response of a resistancebreaking population of Meloidogyne arenaria on Vitis spp., Pakistan Journal of Nematology, 34: 28-33.

Bendixen, LE, DA Reynolds, and RM Reidel. 1979. bibliography of weeds as reservoirs for organisms influences Nematodes. Res.

Castillo, P., and Volvas, N. 2007. Pratylenchus (Nematoda: Pratylenchidae): Diagnosis, Biology, Pathogenicity, and Management. Nematology Monographs and Perspectives, Vol. 6. Brill, Leiden, The Netherlands. doi:10.1163/ej. 9789004155640.i-52

Ditjenbun. 2012. Coffee. Directorate General of Plantations. Jakarta

Evans, K. 1982. Water use, calcium uptake, and tolerance of cyst nematode attack in potatoes. Potato Research 25: 71-88.

Mustika, Ika, 2005. Conception and Control Strategy for Plant Plant Parasitic Nematodes in Indonesia. Spice Crops Research Institute and Indonesian Spices and Medicinal Crops Research Institute Medicines Jl. Student Army No. 3, Bogor 16111.

Perkasa, Suria, 2011. Weed Control. FP. UISU (2010-2011). Islamic University of North Sumatra.

Brawijaya, Malang. 194 p. Swibawa, Igede. 2009. PARASITE NEMATODES IN COFFEE PLANTS. University of Lampung.

Bioedukasi Vol. XVI. No. 2 Oktober 2018 
Tjokrowardojo, USA and E. Djauhariya. 2013. Weed in Ginger Plant Cultivation. Research Institute for Medicinal and Aromatic Plants. Bogor.

Weed Technology October 2010. Host Weed Root - Nematode Knots and Distribution. The role of weeds in the management of nematodes. DOI: 10.1614 / WS-04-053R. 1 CITATIONS 